DOI: 10.20472/EFC.2019.011.015

IRIDA VEJSIU

Societe Generale Albania Bank, Albania

\title{
EMPLOYEE TURNOVER IMPACT ON THE PROFITABILITY OF THE BANKS- THE CASE OF THE ALBANIAN BANKING SYSTEM
}

\begin{abstract}
:
This research study has been focused on the impact the employee turnover can have for the banks in Albania. High rates of the voluntary turnover among the banking employees can affect the business results. The negative impact might be higher when the turnover has been among the highly professional employees covering key areas of expertise. The research methodology used has been the case study. The data have been collected from statistical documents and archives and $75 \%$ of the banks operating in the market have been included in the study. The study found an increasing trend in the employee turnover over the last three years for most of the banks, however when it comes to the profitability it has not been evidenced a clear trend for the banks, there is a lot of fluctuations on their net profit. Somehow due to this fluctuation the regression model built to test the connection among the turnover and banks profitability come out to have no statistical importance.
\end{abstract}

\section{Keywords:}

Employee's turnover, Banking, Profitability, Albanian Banking System

JEL Classification: J63, J24, J30 


\section{Introduction}

The employee turnover has captured the attention of many authors over the years due to the impact it has for the organizations. There are many studies that have been held to cover such topic. This is because human capital has an important impact for the organizations nowadays.

Some authors such as Kreitner (2003) and Nuget (2009), defines the employee turnover as the rate or percentage of the staff leaving the organizations versus the ones actually working for it. On the other hand (Morell et al. 2004) define employee turnover not simply as rate but something more, which relates to the emotional aspect as well.

The research aims to analyses mostly the impact of two major categories of the employee turnover, i.e. voluntary and involuntary turnover, Memon et al. (2016). The literature review in such regard provides different perspectives of its impact, such as for example: the turnover impact on the organizations overall costs, accentuated this in the Hay Group (2014) study.

Authors such as (Ployhart et al. 2014; Pollitt 2000; Shore and Martin,1989; Ton and Huckman 2008) come to the conclusion that the impact of the staff turnover is not simply related to the increase of the staff costs, but it is also related to the company overall performance.

\subsection{Statement of Problem}

According to (Hackman and Pisano 2006; Shaw et al. 2005a, 2005b, 2009; Sieben and Zubanov 2009) the same employee turnover can impact differently organizations. This is related mostly due to different factors depending on the quality of the staff leaving the organization for example, costs associated with the recruitment and selection of the replacing employees.

This study seeks to assess the impact of the employee turnover for the organizations.

\subsection{Objectives of the Study}

The research aims to achieve the following objectives:

1. To identify the level of turnover in the banking system in Albania

2. To determine the impact of the employee turnover in the organizational performance

3. To determine the impact of the high employee turnover in the organizational performance 


\section{Literature Review}

\subsection{Definition}

While searching different articles related to the definition of the employee turnover for an organization, there were many authors that have conducted their research in this subject and many definitions have been given related to the employee turnover. Kreitner (2003) for example defines the employee turnover as the rate of terminations from the staff which needs to be replaced by another employee.

Another author which defines the employee turnover as a rate/percentage is also Nuget (2009), he emphasize that the employee turnover is a percentage/the rate of employees leaving the institution and the ones joining the company.

There are other authors which defines the employee turnover from another perspective, they do not consider it as a simple rate or percentage but they take into consideration also the psychological connection with the company, in other words the emotional relation.

Employee turnover in such perspective is "how long an employee stays connected to one organization". Who much connected is the employee with the company and how ready is he willing to leave the company for another one, this is also defined as the turnover intention. (Udechukwu \& B, 2007)

According to authors such as (Brawley \& Pury, 2016; Bureau of labor statistics, 2012; Hom, Mitchell, Lee, \& Griffeth, 2012) when there is complete separation from a company in a form of: cessations, resignations, layoffs, and discharges, this is defined as the employee turnover.

(Morell et al. 2004) gives as well an emphasize on the emotional element when defining the employee turnover. According to him the employee turnover is the termination of both employment contract and of the emotional physiological contract.

In fact it is very interesting this perspective of defining the employee turnover as not only a simple termination but also the emotional impact it has for the involved target groups both directly and indirectly.

\subsection{Types of employee turnover}

What type of employee turnover are the most frequent ones and in what perspective have been defined in the research studies.

Memon et al. (2016) has identified two major type of employee turnover for a company/ organization. i.e.: involuntary and voluntary turnover. 
The definition of involuntary turnover given by Cao et al. (2013), is related to the fact that the closure of the contract is initiated from the company and not by the employee himself. While the voluntary turnover is when the contract closure is initiated from the employee.

Dess et al. (2001), considers voluntary turnover to add costs to the organizations which come both from the direct costs, related to replacement, recruitment and selection, temporary staff, management time, etc, and the indirect costs which come as a result of the loss of the so called social capital, such as morale, pressure on remaining staff, costs of learning, product/ service quality, organizational memory etc.

\subsection{Reasons of employee turnover}

Different authors have identified different reasons which brings the staff to the decision of terminating the contract with the current company/organization. And it is true the decision for an employee to quit working for a certain company can come as a result of many reasons some simple and some very complex ones.

Fitz-Enz (2009) underlines that the majority of the turnovers are happening only due to the behavior demonstrated by their direct supervisors. This is also considered as the main/ number one reason the staff decided to leave the company. While the second underlined reason for staff turnover is the opportunity given to the staff for growth, when there is a lack of such opportunities, the staff decides to leave.

Most of us might have expected to see the pay level as the main reason of the staff turnover, but in fact it is not the case and it has been evaluated that $80 \%$ of the turnovers for organizations are not related to the pay level but there are other factors associated with such decision. Such facts include mostly the daily actions of the direct manger in regard to the staff engagement, performance feedback, career discussions, job redesign, and other possible soft solutions. Fitz-Enz (2010)

Ibrahim, Usman \& Bagudu, (2013) in their study accentuated that there are two main factors for the staff to leave the company, the first one is related to the level of satisfaction the employee has within the organization and the second is for other reasons which are not related to their job satisfactions. So it is import to divide these two categories.

Herzberg et al. (1959) motivational theory underlines the following motivational reasons for an employee such as a) achievement, b) recognition, c) employee's perception, d) responsibility, e) advancement, and f) possibility of growth. While Hertzberg in his theory point out also the main factors causing dissatisfaction among staff i.e. a) job security, b) organization commitment, c) work environment and conditions, d) working relationships, e) supervision, and f) incentives. 
In the meantime the research performed by Lee et al. (1994), identify that almost $63 \%$ of the staff contract closures came as a results of the so called "triggering event", that happened or something that happened in the company such as no internal equity or that they might not consider themselves in line for the promotion, and many other reasons alike.

\subsection{Impact of employee turnover}

What impact can have a high employee turnover rate for the organization? There are many authors providing different perspectives on their studies related to the impact the turnover can have.

The employee turnover is costly for the organization, Hay Group in their study conducted in 2014 has identified that to the organization replacing an employee can costs up to 12 month salaries. On the other hand also Km (2012) has identified staff turnover as costly for the company. According to Dingeer et al, (2012) loosing professional and skilled staff cannot be affordable from the companies and one of the main reason associated with this is also the cost.

Now days all over the world organizations have realized the importance of their staff and the impact the staff turnover can have on the performance of the employees and of the organization as well which due to the turnover can be slowed down. The staff turnover impact the increase of the expenses which are related with the recruitment and training of the new staff. Chen, Lin \& Lien, (2010).

Grobler et al. (2006) in his study takes a positive perspective related to the impact of the turnover for the organization he accentuates that somehow organization expect to have some turnover and this can be even beneficial, but up to a certain extent because a high level of turnover can have very negative results such as an unstable workforce, can bring increase in the HR costs, etc.

Another perspective related to the costs of the staff turnover come for Terborg and Lee (1984), they conclude that the staff turnover is costly due to the consequences related to the termination/ replacement of the existing staff such as advertising, recruitment, selection and hiring, etc.

The loss of a skilled employee is considered much costly of the organization if compared to a loss of a semiskilled or an un-skilled employee. Sager, Griffeth and Hom, (1998)

There are also evidences from different authors that the same turnover rate can have different impact on companies. This is related mostly due to different factors depending on the quality of the staff leaving the organization for example. ( Hackman and Pisano 2006; Shaw et al. 2005a, 2005b, 2009; Sieben and Zubanov 2009) 
The human capital theory underlines the negative impact of the staff turnover in the organizational performance, because the leaving staff can be associated with the loss of the organizational memory, loss of knowledge and skills the staff has developed within the company due to their experience and training. (Ployhart et al. 2014; Pollitt 2000).

While according to the social capital theory high turnover rate impact negatively on the relations, social ties and trust among the colleagues. (Leana and Van Burren 1999)

The staff turnover is considered so crucial for the companies nowadays so that it has been considered that it has an indispensable impact on the profitability/ financial performance of the business. Such perspective has been accentuated by many authors in their studies. Shore and Martin, (1989) for example emphasize that keeping the skilled employees in the organization is crucial to keep the level of profitability stable.

Higher turnover rates are the cause of a decrease in the level of productivity Batt (2002) of customer service Kacmar et.al. (2006) and profits Ton and Huckman (2008)

Mathis \& Jackson (2007) argues that the turnover results in impacting the existing employees with additional workload which can impact their performance and the effectiveness of organization as well.

The human capital perspective suggests "that workers add value to a firm because they possess capabilities (e.g., knowledge, skills and abilities) that support organizational functioning and productivity". "Turnover negatively affects performance because it depletes this collective level knowledge and experience" (Batt 2002, Kacmar et. al. 2006, Koys 2001)

Considering this great impact of the turnover is there any solution for the organizations in reducing the employee turnover? There are some authors who have reached some conclusions in such perspective.

When it comes to the success of organization Osteraker (1999) outlined that there are two main pillars it depends on, i.e. retention and employee satisfaction

Abdul \& Kaleem (2014) on the other side suggest as the solution of the turnover is the increase in the benefits organizations pay toward their employees rather than on the compensation.

While according to Moynihan and Pandey (2008) the key in reducing the turnover intention from the staff are the creation of strong intra-organizational networks. 


\section{Methodology}

The case study approach has been used for this research. In such regard Yin (2009) recommends six sources- Documentation, Archival Records, Interviews (or surveys), direct observation, Participant observation and Physical artifacts, in order to run the case study research in the proper way.

In this study has been analyzed the turnover in the banking system in Albania for three consecutive years and in the meantime has been analyzed the profitability of these banks.

The data has been collected from the Albanian Association of Banks both in relation to the turnover and to the profitability of each bank. Despite the fact that the Banking system operates with 16 banks, we were able to collect the entire data for 12 banks only. Some of the banks have not provided the data at least for one year, so in such regard the analysis of the data have been performed for 12 banks out of 16 in total that have been operating in the banking market in Albania as of December 2017.

Taking into consideration the literature review performed on the topic, which frequently emphasize a connection among the voluntary turnover impacting profitability of an organization, the purpose of the study has been to test whether there is such a relation among the baking system turnover and its profitability. In such regard a regression model has been built with the data received.

\section{Results}

Figure 1: Total Turnover of Banks in Albania

\section{Total Turnover of Banks in Albania}

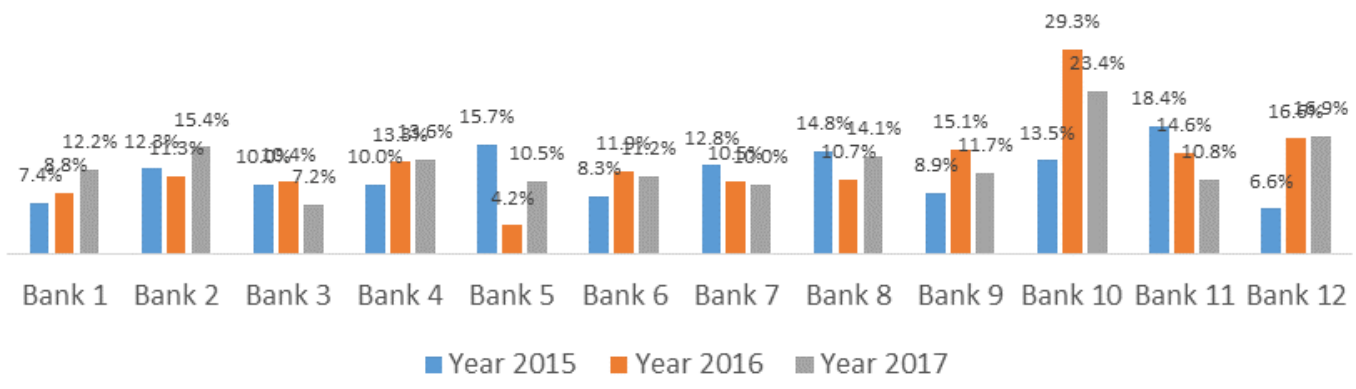

Source: Own adjustment based on AAB (Albanian Association of Banks) data 
Figure 2: Voluntary Turnover of Banks in Albania

\section{Voluntary Turnover of Banks in Albania}

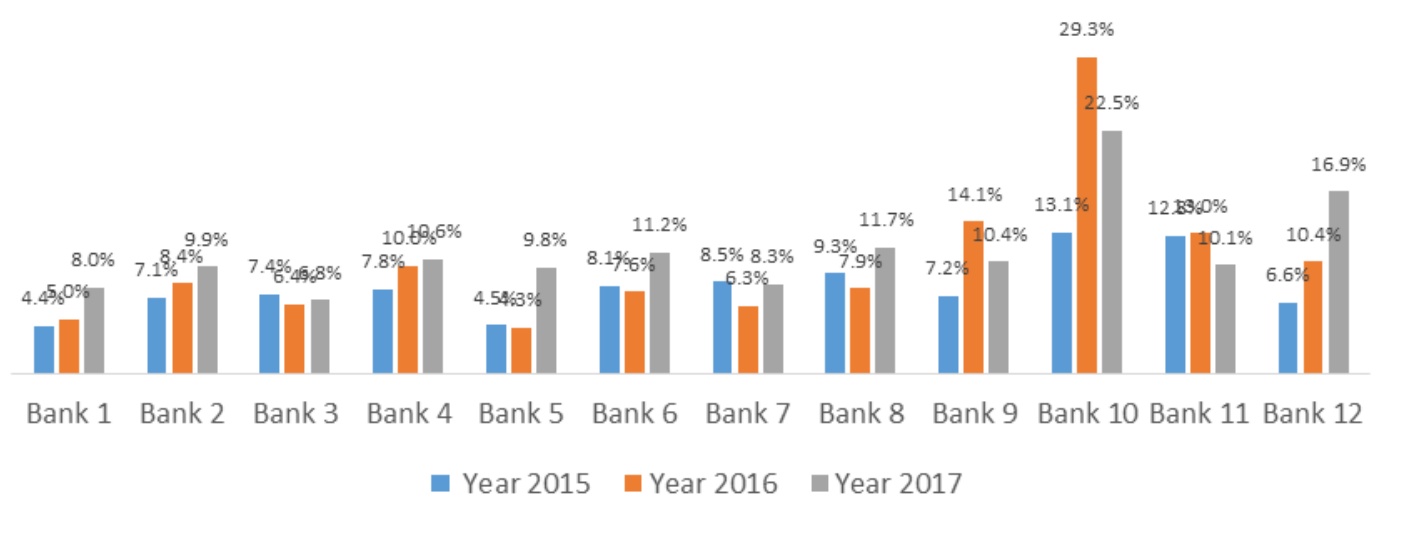

Source: Own adjustment based on AAB (Albanian Association of Banks) data

\section{Figure 3: Net Profit of Banks in Albania}

Net Profit of Banks in Albania

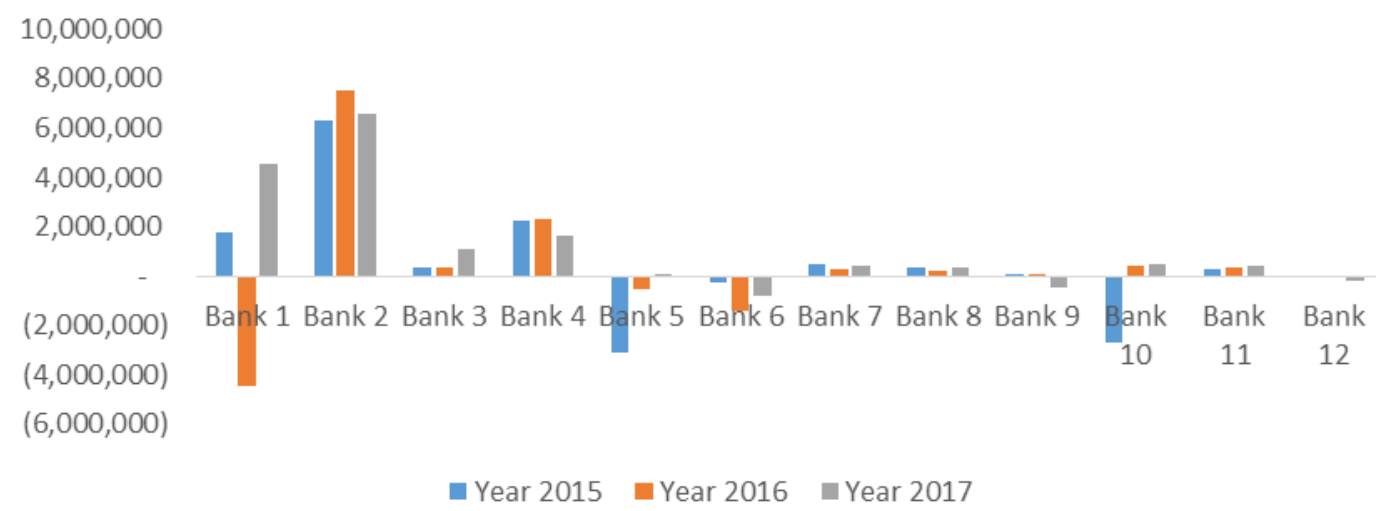

Source: Own adjustment based on AAB (Albanian Association of Banks) data

\subsection{The empirical model}

Our aim was to calculate the impact of both total and the voluntary turnover on the financial performance of the business.

In order to understand the impact of the turnover on the financial impact of a banking institution in Albania, was build the following regression model to test the hypothesis:

$$
\mathrm{Y}=\mathrm{a} 0+\mathrm{a} 1 \mathrm{X} 1
$$


Where independent variable is:

X1= Total Turnover

And Dependent variable is:

$Y=$ Financial performance of the business

This way we aim to test the impact of the turnover on the financial performance of the business. The hypothesis of the theoretical model are as follows:

$\mathrm{H} 0: \mathrm{a} 1=0$

$\mathrm{Ha}$ : The variables is different than 0.

As shown in the following table where the regression model is not statistically significant when tested this hypotheses for the data of the year 2015, while the same scenario has been observed when tested for the years 2016 and 2017 as well and when tested even with the data related to the voluntary turnover.

Table 1: Regression Statistics( Year 2015)

\begin{tabular}{lr}
\hline \multicolumn{2}{c}{ Regression Statistics } \\
\hline Multiple R & 0.133328625 \\
R Square & 0.017776522 \\
Adjusted R & - \\
Square & 0.073132569 \\
Standard Error & 2410318.973 \\
Observations & 12 \\
\hline
\end{tabular}

\begin{tabular}{|c|c|c|c|c|c|c|}
\hline & $d f$ & & $S S$ & $M S$ & $F$ & $\begin{array}{c}\text { Significance } \\
F \\
\end{array}$ \\
\hline Regression & & 1 & $1.15659 \mathrm{E}+12$ & $1.15659 \mathrm{E}+12$ & 0.199080708 & 0.664969788 \\
\hline Residual & & 11 & $6.3906 E+13$ & $5.80964 \mathrm{E}+12$ & & \\
\hline Total & & 12 & $6.50626 \mathrm{E}+13$ & & & \\
\hline
\end{tabular}

\begin{tabular}{lrccccc}
\hline & \multicolumn{3}{c}{ Standard } & & & \\
& Coefficients & Error & t Stat & $P$ Value & Lower 95\% & Upper 95\% \\
\hline $\begin{array}{l}\text { Intercept } \\
\text { Total Turnover }\end{array}$ & 0 & \#N/A & \#N/A & \#N/A & \#N/A & \#N/A \\
X1 & 2572361.842 & 5765241.053 & 0.446184612 & 0.664119294 & 10116848.16 & 15261571.84 \\
\hline
\end{tabular}

While in order to determine the impact of the high employee turnover on the profitability for the banks under the study, we have tested the above linear regression model only for the banks that have a voluntary turnover higher than $10 \%$ during the year 2017.

Even this model does not show a statistical importance. 
Table 2: Regression Statistics for the voluntary turnover higher than $10 \%$ ( Year 2015)

\begin{tabular}{lr}
\hline \multicolumn{2}{c}{ Regression Statistics } \\
\hline Multiple R & 0.267200735 \\
R Square & 0.071396233 \\
Adjusted R Square & -0.095270434 \\
Standard Error & 808672.6459 \\
Observations & 7 \\
\hline
\end{tabular}

\begin{tabular}{|c|c|c|c|c|c|c|}
\hline & $d f$ & & SS & Ms & $F$ & $\begin{array}{c}\text { Significance } \\
F\end{array}$ \\
\hline Regression & & 1 & $3.02 \mathrm{E}+11$ & $3.02 E+11$ & 0.461313 & 0.527172684 \\
\hline Residual & & 6 & $3.92 \mathrm{E}+12$ & $6.54 \mathrm{E}+11$ & & \\
\hline Total & & 7 & $4.23 E+12$ & & & \\
\hline
\end{tabular}

\begin{tabular}{|c|c|c|c|c|c|c|}
\hline & Coefficients & $\begin{array}{c}\text { Standard } \\
\text { Error }\end{array}$ & $t$ Stat & $P$ Value & Lower 95\% & $\begin{array}{l}\text { Upper } \\
95 \%\end{array}$ \\
\hline Intercept & 0 & $\# \mathrm{~N} / \mathrm{A}$ & $\# \mathrm{~N} / \mathrm{A}$ & $\# \mathrm{~N} / \mathrm{A}$ & $\# \mathrm{~N} / \mathrm{A}$ & $\# \mathrm{~N} / \mathrm{A}$ \\
\hline Total Turnover X1 & 1480294.054 & 2179465 & 0.679201 & 0.522334 & -3852665.21 & 6813253 \\
\hline
\end{tabular}

\section{Discussion}

- Objective one was to find out the level of employee turnover of the banks in Albania. The study found as indicated in Graph 1 and 2 that the level of the turnover in the banking system has an increasing trend over the years for the majority of the banks considered in the study.

- Objective two was to determine the impact of the employee turnover on the organizational financial performance. The study found out based on the regression model build to test the hypothesis that only with the one factor such as employee turnover the regression model built does not have a statistical importance.

- Objective three was to determine the impact of the high employee turnover. The study found out that as specified in the regression analysis table no. 2 . The regression model was not of a statistical importance. 


\section{Conclusion}

Might have been different reasons for such results. As seen from the net profitability over the last three years there is quite a big volatility for some of the banks going from profits to losses for example. While when it comes to the voluntary turnover data, it is observed an increase over the years for the majority of the banks. It is clear that the voluntary turnover has an obvious increase trend over the last three years, while there is no clear trend in terms of profitability for the banks considered in the study. Some of the banks have slightly improved their financial performance and some others are having a deteriorating trend in terms of their net profit. In such perspective there might have been different factors impacting their financial results. Measuring solely the impact of the turnover over the bank's profitability might not provide the relevant relation, while it might be considered further studying the impact the turnover has for the organizations together with other indicators which might have impact in their profitability.

\section{ANNEX I}

Table 3: Regression Statistics Total Turnover Impact (Year 2016)

\begin{tabular}{lr}
\hline \multicolumn{2}{c}{ Regression Statistics } \\
\hline Multiple R & 0.183401102 \\
R Square & 0.033635964 \\
Adjusted R & \\
Square & -0.057273127 \\
Standard Error & 2715239.583 \\
Observations & 12 \\
\hline
\end{tabular}

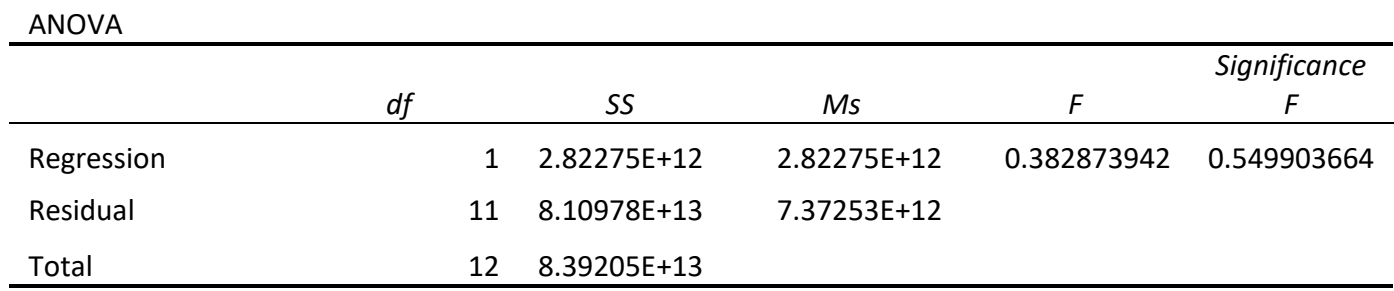

\begin{tabular}{lccccrr}
\hline & Coefficients & $\begin{array}{c}\text { Standard } \\
\text { Error }\end{array}$ & t Stat & P Value & Lower 95\% & Upper 95\% \\
\hline Intercept & 0 & $\#$ \#/A & \#N/A & \#N/A & \#N/A & \#N/A \\
Total Turnover X1 & 3394744.479 & 5486295.379 & 0.618768084 & 0.548668527 & 8680510.234 & 15469999.19 \\
\hline
\end{tabular}


Table 4: Regression Statistics Total Turnover Impact (Year 2017)

\begin{tabular}{lr}
\hline \multicolumn{2}{c}{ Regression Statistics } \\
\hline Multiple R & 0.495666653 \\
R Square & 0.245685431 \\
Adjusted R Square & 0.15477634 \\
Standard Error & 2177582.671 \\
Observations & 12 \\
\hline
\end{tabular}

ANOVA

\begin{tabular}{|c|c|c|c|c|c|}
\hline & $d f$ & SS & Ms & $F$ & Significance $F$ \\
\hline Regression & 1 & $1.6989 \mathrm{E}+13$ & $1.6989 \mathrm{E}+13$ & 3.582775475 & 0.087653492 \\
\hline Residual & 11 & $5.21605 E+13$ & $4.7419 \mathrm{E}+12$ & & \\
\hline Total & 12 & $6.91496 \mathrm{E}+13$ & & & \\
\hline
\end{tabular}

\begin{tabular}{lrccccc}
\hline & Coefficients & Standard Error & t Stat & P Value & Lower 95\% & Upper 95\% \\
\hline Intercept & 0 & \#N/A & \#N/A & \#N/A & \#N/A & \#N/A \\
Total Turnover X1 & 8701077.197 & 4596880.621 & 1.89282209 & 0.084976016 & -1416588.832 & 18818743.2 \\
\hline
\end{tabular}

Table 5: Regression Statistics Voluntary Turnover Impact (Year 2015)

\begin{tabular}{lr}
\hline \multicolumn{2}{c}{ Regression Statistics } \\
\hline Multiple R & 0.133867388 \\
R Square & 0.017920478 \\
& - \\
Adjusted R Square & 0.072988613 \\
Standard Error & 2410142.337 \\
Observations & 12 \\
\hline
\end{tabular}

\begin{tabular}{|c|c|c|c|c|c|c|}
\hline & $d f$ & SS & Ms & $F$ & Significance $F$ & \\
\hline Regression & 1 & $1.16595 \mathrm{E}+12$ & 1.16595E+12 & 0.20072229 & 0.663688492 & \\
\hline Residual & 11 & $6.38966 \mathrm{E}+13$ & $5.80879 \mathrm{E}+12$ & & & \\
\hline \multirow[t]{2}{*}{ Total } & 12 & $6.50626 \mathrm{E}+13$ & & & & \\
\hline & Coefficients & $\begin{array}{c}\text { Standard } \\
\text { Error }\end{array}$ & t Stat & P Value & Lower 95\% & $\begin{array}{c}\text { Upper } \\
95 \%\end{array}$ \\
\hline Intercept & 0 & $\# N / A$ & $\# N / A$ & $\# \mathrm{~N} / \mathrm{A}$ & $\# N / A$ & $\# N / A$ \\
\hline Voluntary Turnover X1 & 3680309.333 & 8214601.826 & 0.448020417 & 0.66283406 & -14399907.38 & 21760526 \\
\hline
\end{tabular}


Table 6: Regression Statistics Voluntary Turnover Impact (Year 2016)

\begin{tabular}{lr}
\hline \multicolumn{2}{c}{ Regression Statistics } \\
\hline Multiple R & 0.19118983 \\
R Square & 0.03655355 \\
Adjusted R Square & -0.0543555 \\
Standard Error & 2711137.64 \\
Observations & 12 \\
\hline
\end{tabular}

ANOVA

\begin{tabular}{|c|c|c|c|c|c|}
\hline & $d f$ & SS & Ms & $F$ & Significance $F$ \\
\hline Regression & 1 & $3.06759 \mathrm{E}+12$ & $3.06759 \mathrm{E}+12$ & 0.4173445 & 0.53280912 \\
\hline Residual & 11 & $8.08529 \mathrm{E}+13$ & $7.35027 \mathrm{E}+12$ & & \\
\hline Total & 12 & $8.39205 E+13$ & & & \\
\hline
\end{tabular}

\begin{tabular}{lrccccc}
\hline & \multicolumn{5}{c}{ Standard } \\
& Coefficients & Error & t Stat & P Value & Lower 95\% & Upper 95\% \\
\hline Intercept & 0 & $\#$ N/A & \#N/A & \#N/A & \#N/A & $\#$ \#/A \\
Voluntary Turnover X1 & 4187579.28 & 6482099.523 & 0.646022059 & 0.5315112 & -10079425.58 & 18454584.1 \\
\hline
\end{tabular}

\section{Table 7: Regression Statistics Voluntary Turnover Impact (Year 2017)}

\begin{tabular}{lr}
\hline \multicolumn{2}{c}{ Regression Statistics } \\
\hline Multiple R & 0.33810789 \\
R Square & 0.11431694 \\
Adjusted R Square & 0.01431694 \\
Standard Error & 2069503.03 \\
Observations & 11 \\
\hline
\end{tabular}

\begin{tabular}{|c|c|c|c|c|c|c|}
\hline & $d f$ & SS & Ms & $F$ & Significance $F$ & \\
\hline Regression & 1 & $5.52795 \mathrm{E}+12$ & $5.52795 \mathrm{E}+12$ & 1.290720681 & 0.285261288 & \\
\hline Residual & 10 & $4.28284 \mathrm{E}+13$ & $4.28284 \mathrm{E}+12$ & & & \\
\hline \multirow[t]{3}{*}{ Total } & 11 & $4.83564 \mathrm{E}+13$ & & & & \\
\hline & & Standard & & & & \\
\hline & Coefficients & Error & t Stat & $P$ Value & Lower 95\% & Upper 95\% \\
\hline Intercept & 0 & $\# \mathrm{~N} / \mathrm{A}$ & $\# \mathrm{~N} / \mathrm{A}$ & $\# \mathrm{~N} / \mathrm{A}$ & $\# \mathrm{~N} / \mathrm{A}$ & $\# N / A$ \\
\hline Voluntary Turnover X1 & 5726197.15 & 5040227.758 & 1.136098887 & 0.282408816 & -5504130.144 & 16956524.4 \\
\hline
\end{tabular}




\section{References}

Abdul, G.A., \& Kaleem, U.A. 2014. "employee turnover rate in oil refineries- a case study of pak rab refinery Itd (parko)". In Ahmed, Z., Sabir, S., Khosa, M., Ahmad, I., Bilal, A.M. (2016). Impact of employee turnover on organizational effectiveness in Telecommunication sector in Pakistan. pp. 90.

Argote, L., D. Epple. 1990. Learning curves in manufacturing. In Hausknecht J. P., Holwerda A. J. (2013) When does employee turnover matter? Dynamic member configuration, Productive capacity, and collective performance. pp.3.

Argote, L. 1999. Organizational learning: Creating, retaining and transferring, knowledge. In Wynen, J., Van Dooren W., Mattijs, J., Deschmps, C. 2018.Linking turnover to organizational performance; the role of process conformance. pp. 4-5.

Batt, R. 2002. Managing customer service: Human Resources practices, quit rates, and sale growth. In Hausknecht J. P., Holwerda A. J. (2013) When does employee turnover matter? Dynamic member configuration, Productive capacity, and collective performance. pp.9.

Brawley, A.M., \& Pury, C. L. (2016). Work experiences on MTurk: Job satisfaction, turnover, and information sharing. In Bryant, O. A. 2017. Employee turnover in the long-term care industry. pp. 9.

Bureau of Labor Statistics. ( 2012). United States Department of Labor; Job openings and labor turnover summary. In Bryant, O. A. 2017. Employee turnover in the long-term care industry. pp. 9.

Cao, Z., Chen, J., Song, Y. (2013). Does total rewards reduced the core employees' turnover intention. . In Al-Habil, W. I., Allah, A. Shehadah, M. (2017) Factors affecting the employees' turnover at the Ministry of High Education in Gaza Governorates- Case Study: North and West Gaza Directorates of Education.

Chen, M.f. Lin, C.P., \& Lien, G. Y. 2010. Modeling job stress as a mediating role in predicting turnover intention. In Ahmed, Z., Sabir, S., Khosa, M., Ahmad, I., Bilal, A.M. (2016). Impact of employee turnover on organizational effectiveness in Telecommunication sector in Pakistan. pp. 88.

Dess, G.G., J.D. Shaw (2001). Voluntary turnover, social capital, and organizational performance. In Hausknecht J. P., Holwerda A. J. (2013) When does employee turnover matter? Dynamic member configuration, Productive capacity, and collective performance. pp.3.

Dess, G.D., Shaw, J.D. ( 2001). Voluntary turnover, social capital, and organizational performance. In AlHabil, W. I., Allah, A. Shehadah, M. (2017) Factors affecting the employees' turnover at the Ministry of High Education in Gaza Governorates- Case Study: North and West Gaza Directorates of Education.

Dinger, M., Thtcher, J.B., Stepina, L.P., \& Craig, K. (2012). The grass is always 123 greener on the other side: test of present and alternative job utility on IT professional's turnover. In Bryant, O. A. 2017. Employee turnover in the long-term care industry. pp. 1.

Fitz-Enz, J. (2009). In J. Fitz- Enz, The ROI of Human Capital. In Liu, J.L. (2014). Main causes of voluntary turnover: A study of factors and their relationship with expectations and preferences. pp. 9.

Fitz-Enz, J.,( 2010). The new HR- Analytics. In Liu, J.L. (2014). Main causes of voluntary turnover: A study of factors and their relationship with expectations and preferences. pp. 9. 
Grobler, P.A., S. Warnich, M.R. Carrel, N.F . Elbert and R.D. Hatfild, 2006. Human Resources Management in South Africa. . In Ampomah P, Cudjor K S , 2015 The effect of employee Turnover on Organizations ( Case Study of Electricity Company of Ghana, Cape Coast).

Hausknecht J. P., Holwerda A. J. (2013) When does employee turnover matter? Dynamic member configuration, Productive capacity, and collective performance. pp.7-10.

Hay Group. (2014). How to stop your talent taking flight. . In Liu, J.L. (2014). Main causes of voluntary turnover: A study of factors and their relationship with expectations and preferences. pp. 3.

Herzberg, F., Mausner, B., \& Snyderman, B. (1959). The motivation to work ( $2^{\text {nd }}$ ed.) In Bryant, O. A. 2017. Employee turnover in the long-term care industry. pp. 8.

Hom, P. W., Mitchell, T. R., Lee, T. W., \& Griffeth, R. W. ( 2012). Reviewing employee turnover: focusing on proximal withdrawal states and an expanded criterion. In Bryant, O. A. 2017. Employee turnover in the long-term care industry. pp. 9.

Huckman, R.S., G.R. Pisano. (2006). The firm specificity of individual performance: Evidence from Cardiac surgery. In Hausknecht J. P., Holwerda A. J. (2013) When does employee turnover matter? Dynamic member configuration, Productive capacity, and collective performance. pp. 10.

Kacmar, K.M. , M. C. Andrews, D.L. Van Roy, R.C. Steilberg, S. Cerrone. 2006. Sure everyone can be replaced...but at what cost? Turnover as a predictor of unit-level performance. In Hausknecht J. P., Holwerda A. J. (2013) When does employee turnover matter? Dynamic member configuration, Productive capacity, and collective performance. pp.9.

Kim, S. (2012). The impact of human resource management on state government IT employee turnover intentions. In Bryant, O. A. 2017. Employee turnover in the long-term care industry. pp. 1.

Koys, D. J. 2001. The effects of employee satisfaction, organizational citizenship behavior, and turnover on organizational effectiveness: A unit-level, longitudinal study. In Hausknecht J. P., Holwerda A. J. (2013) When does employee turnover matter? Dynamic member configuration, Productive capacity, and collective performance. pp. 9.

Kreitner, R., (2003). Human Resources management. Toronto: Arizona State University in Ampomah P, Cudjor K S , 2015 The effect of employee Turnover on Organizations ( Case Study of Electricity Company of Ghana, Cape Coast).

Leana, C. R., H.J. Van Buren. 1999. Organizational Social Capital and employment practices. In Wynen, J., Van Dooren W., Mattijs, J., Deschmps, C. 2018.Linking turnover to organizational performance; the role of process conformance. pp. 3.

Lee, T., \& Mitchell, T. (1994). An Alternative approach: The unfolding model of voluntary employee turnover. In Liu, J.L. (2014). Main causes of voluntary turnover: A study of factors and their relationship with expectations and preferences. pp. 9.

Mathis, R. B., \& Jackson, J.H. (2007). Human Resources Management (10 th ed.). In Ahmed, Z., Sabir, S., Khosa, M., Ahmad, I., Bilal, A.M. (2016). Impact of employee turnover on organizational effectiveness in Telecommunication sector in Pakistan. pp. 90. 
Meier, K.J., A. Hicklin. 2008. Employee turnover and organizational performance: Testing a hypothesis from classical public administration. In Wynen, J., Van Dooren W., Mattijs, J., Deschmps, C. 2018.Linking turnover to organizational performance; the role of process conformance. pp. 4.

Memon, M. A. ., Salleh, R., Baharom, N.M.R., Garavan, T. (2016). The link between training satisfaction, work engagement and turnover intention. In Al-Habil, W. I., Allah, A. Shehadah, M. (2017) Factors affecting the employees' turnover at the Ministry of High Education in Gaza Governorates- Case Study: North and West Gaza Directorates of Education.

Morgeson, F.R., D.A. Hofman. 1999. The structure and function of collective constructs: Implications for multilevel research and theory development. In Hausknecht J. P., Holwerda A. J. (2013) When does employee turnover matter? Dynamic member configuration, Productive capacity, and collective performance. pp.4.

Moynihn, D.P., S.K. Pandey. 2008. The ties that bind: Social networks, person organization value fit, and turnover intention. In Wynen, J., Van Dooren W., Mattijs, J., Deschmps, C. 2018.Linking turnover to organizational performance; the role of process conformance. pp. 3.

Morrel, K., Loan-Clarke, J., Wilkinson, A. J., (2004). Organizational change and employee turnover. In AlHabil, W. I., Allah, A. Shehadah, M. (2017) Factors affecting the employees' turnover at the Ministry of High Education in Gaza Governorates- Case Study: North and West Gaza Directorates of Education.

Nelson, Richard R. 1982. An evolutionary theory of economic change. In Wynen, J., Van Dooren W., Mattijs, J., Deschmps, C. 2018.Linking turnover to organizational performance; the role of process conformance. pp. 4-5.

Nuget, A., 2009. Using voluntary benefits strategically can help employer's goals of retaining employees and controlling costs. in Ampomah P, Cudjor K S , 2015 The effect of employee Turnover on Organizations ( Case Study of Electricity Company of Ghana, Cape Coast).

Osteraker, M. C. 1999. Measuring motivation in learning organization. In Ahmed, Z., Sabir, S., Khosa, M., Ahmad, I., Bilal, A.M. (2016). Impact of employee turnover on organizational effectiveness in Telecommunication sector in Pakistan. pp. 89.

Ployhart, R. E., A.J. Nyberg, G. Reilly, M. A. Maltarich. 2014. Human Capital is dead: Long live human capital resources. In Wynen, J., Van Dooren W., Mattijs, J., Deschmps, C. 2018.Linking turnover to organizational performance; the role of process conformance. pp. 3.

Pollitt, C. 2000. Institutional Amnesia: A paradox of the "Information Age"? . In Wynen, J., Van Dooren W., Mattijs, J., Deschmps, C. 2018.Linking turnover to organizational performance; the role of process conformance. pp. 3.

Price, J. L. 1977. The study of turnover. In Hausknecht J. P., Holwerda A. J. (2013) When does employee turnover matter? Dynamic member configuration, Productive capacity, and collective performance. pp.3.

Sager, J.K., Griffeth, R.W., Hom, P.W.( 1998). A comparison of structural models representing turnover cognitions. In Hossain S. M., Rahman. T. M. S., Labony. S.S. (2015) Effects of Recruitment and Selection Process on Employee Turnover and its consequences on organization's profitability- A study on financial sector of Bangladesh. 
Sarah, B., Gaia, G., \& Christopher, M. 2007. Labor turnover and firm performance. In Ahmed, Z., Sabir, S., Khosa, M., Ahmad, I., Bilal, A.M. (2016). Impact of employee turnover on organizational effectiveness in Telecommunication sector in Pakistan. pp. 88.

Shaw J.D., N. Gupta, J.E. Delery. 2005a. Alternative conceptualization of the relationship between voluntary turnover and organizational performance. In Hausknecht J. P., Holwerda A. J. (2013) When does employee turnover matter? Dynamic member configuration, Productive capacity, and collective performance. pp. 10.

Shaw, J. D., M.K. Duffy, J.L.Johnson, D.E. Lockhart. 2005b. Turnover, social capital losses, and performance. . In Hausknecht J. P., Holwerda A. J. (2013) When does employee turnover matter? Dynamic member configuration, Productive capacity, and collective performance. pp. 10

Shaw , J.D., B.R. Dineen, R. Fang, R.F. Vellella. 2009. Employee-organization exchange relationships, HRM practices, and quit rates of good and poor performers. In Hausknecht J. P., Holwerda A. J. (2013) When does employee turnover matter? Dynamic member configuration, Productive capacity, and collective performance. pp. 10.

Shore, L.M., Martin, H.J. (1989). Job Satisfaction and organizational commitment in relation to work performance and turnover intentions. .). In Hossain S. M., Rahman. T. M. S., Labony. S.S. (2015) Effects of Recruitment and Selection Process on Employee Turnover and its consequences on organization's profitability- A study on financial sector of Bangladesh.

Sieben, W.S., N. Zubanov. 2009. Searching for the optimal level of employee turnover: A study of a large U. K. retail organization. In Hausknecht J. P., Holwerda A. J. (2013) When does employee turnover matter? Dynamic member configuration, Productive capacity, and collective performance. pp. 10.

Staw, B. M. 1980. The consequences of turnover. In Hausknecht J. P., Holwerda A. J. (2013) When does employee turnover matter? Dynamic member configuration, Productive capacity, and collective performance. pp.3.

Terborg, J.R., Lee , T.W. (1984). A predictive study of organizational turnover rates. In Hossain S. M., Rahman. T. M. S., Labony. S.S. (2015) Effects of Recruitment and Selection Process on Employee Turnover and its consequences on organization's profitability- A study on financial sector of Bangladesh.

Ton, Z., R.S. Huckman. 2008. Managing the impact of employee turnover on performance. The role of process conformance. In Hausknecht J. P., Holwerda A. J. (2013) When does employee turnover matter? Dynamic member configuration, Productive capacity, and collective performance. pp.3.

Ton, Z., R. Huckman. 2008. Managing the impact of employee turnover on performance: The role of process conformance. In Wynen, J., Van Dooren W., Mattijs, J., Deschmps, C. 2018.Linking turnover to organizational performance; the role of process conformance. pp. 4-5.

Udechukwu, I.K., \& B, G.M. 2007. Determining the probability that an employee will stay or leave the organization. A mathematical and theoretical model for organizations. )". In Ahmed, Z., Sabir, S., Khosa, M., Ahmad, I., Bilal, A.M. (2016). Impact of employee turnover on organizational effectiveness in Telecommunication sector in Pakistan. pp. 90.

Yin, R. K. (2009). Case study research: Design and methods (4th ed.). In Hossain S. M., Rahman. T. M. S., Labony. S.S. (2015) Effects of Recruitment and Selection Process on Employee Turnover and its consequences on organization's profitability- A study on financial sector of Bangladesh. 
Van Mannen , J ., E. H. Schein ( 1979) Toward of Theory of Organizational Socialization. In Hossain S. M., Rahman. T. M. S., Labony. S.S. (2015) Effects of Recruitment and Selection Process on Employee Turnover and its consequences on organization's profitability- A study on financial sector of Bangladesh.

Wanous, J.P. (1992). Organizational Entry: Recruitment, Selection, Orientation and Socialization of New Commers (2nd ed.). In Hossain S. M., Rahman. T. M. S., Labony. S.S. (2015) Effects of Recruitment and Selection Process on Employee Turnover and its consequences on organization's profitability- A study on financial sector of Bangladesh. 